\author{
제주지역에서 동계사료작물의 사초생산성 및 사료가치 비교 \\ 박형수·황경준 · 박남건 · 최기준*·이종경*·천동원*·고문석
}

\title{
Comparison of Forage Production and Feed Value of Winter Forage Crops in Jeju
}

\author{
Hyung Soo Park, Kyung Jun Hwang, Nam Geon Park, Gi Jun Choi*, Jong Kyung Lee*, \\ Dong Won Cheon* and Moon Suck Ko
}

\begin{abstract}
This experiment was conducted to compare forage production and feed value of winter forage crops at the experimental field of Livestock Division, National Institute of Subtropical Agriculture from 2007 to 2008. The experiment was arranged in a randomized block design with three replications. The five winter forage crops used in this experiment were barely ('Youngyang' and 'Yuyeon'), oats ('Samhan' and 'Swan'), wheat ('Kumkang' and 'Woori'), triticale ('Shinyoung') and italian ryegrass ('Hwasan 101' and 'Florida-80'). The species having the fastest heading date was wheat(5th April) while the heading date of oats ('Samhan') was the latest as 28th April. The dry matter (DM) content of wheat was the highest among the five winter forage crops. Italian ryegrass ('Hwasan 101') showed the highest CP content by $11.2 \%$ and oats (Swan) showed the lowest content by 9.8\%. Average acid detergent fiber (ADF) and neutral detergent fiber (NDF) content were 28.6 and $50.8 \%$ respectively. The five winter forage crops have narrow range of total nutrient digestibility (TDN) from $64.0 \%$ to $69.1 \%$. Italian ryegrass ('Hwasan 101') showed the highest DM yield by $25,951 \mathrm{~kg} / \mathrm{ha}$, but the DM yield of barely and wheat low by $13,892 \mathrm{~kg} / \mathrm{ha}$ ('Yuyeon') and 14,815 $\mathrm{kg} / \mathrm{ha}$ ('Woori'), respectively. Italian ryegrass and oats have higher forage yield and feed value in Jeju. Also, oats has high grain and forage yield. The results demonstrated oats can cultivate as alternative winter forage crop for whole crop silage barely in Jeju.
\end{abstract}

(Key words: Small grain forage, Whole crop silage, Barely, Oats)

$\begin{array}{cc}\text { I . 서 론 } & \text { 서 생산되어져 왔다. 하지만 최근 들어 겨울철 } \\ & \text { 논을 이용한 청보리와 이탈리안 라이그라스의 } \\ \text { 최근 들어 국제 곡물가격 상승 여파로 국내 } & \text { 재배 및 이용이 점차 확대되면서 동계사료작물 } \\ \text { 배합사료 가격이 상승하여 축산농가의 경영난 } & \text { 의 중요성이 부각되고 있다. } \\ \text { 이 가중되고 있는 시점에 축우농가에서는 생산 } & \text { 특히 제주지역은 겨울철 최저평균기온이 높 } \\ \text { 비를 절감할 수 있는 자급 조사료의 생산이 최 } & \text { 고 땅이 얼지 않아 동계사료작물의 월동에 큰 } \\ \text { 대 관심사가 되고 있다. 우리나라의 조사료 생 } & \text { 문제가 없으며 겨울철에도 생육이 가능하여 동 } \\ \text { 산은 대부분 하계 사료작물 중심의 작부체계에 } & \text { 계사료작물의 재배에 우수한 생육 환경조건을 }\end{array}$

난지농업연구소(National Institute of Subtropical Agriculture, Jeju 690-150, Korea)

*농촌진흥청 축산과학원(National Institute of Animal Science, Cheonan 331-801, Korea)

Corresponding author: Hyung Soo Park, National Institute of Subtropical Agriculture, Jeju 690-150, Korea

Tel:+82-64-754-5722, Fax: +82-64-754-5713, E-mail : anpark@rda.go.kr 
가지고 있다.

제주지역의 조사료생산 작부체계에서 동계사 료작물로는 이탈리안 라이그라스가 생산성이 가장 우수한 것으로 나타났으며 (고 등, 1976), 이탈리안 라이그라스 '화산 101호' 품종의 경 우 제주지역에서의 생산성은 중부지방보다 대 체로 높은 것으로 나타났다 (최 등, 2007). 특히 귀리는 중부지방의 경우 주로 단경기 작물로 재배되어지는데 제주지역에서는 겨울철 기후가 온난하여 월동이 가능하며 (최 등, 1993), 곡실 수량이 높아 청보리를 대체 할 수 있는 동계사 료작물로 이용가치가 매우 높을 것으로 기대된 다 (고 등, 2005).

최근 들어 내륙지방은 청보리를 사일리지 형 태로 많이 이용하고 있는데 제주지역의 경우 아직 이탈리안 라이그라스를 제외한 동계사료 작물의 사초생산성과 사료가치 평가에 대한 연 구가 미진한 실정이며, 겨울철 제주지역의 온 난한 기후를 최대한 활용할 수 있는 동계사료 작물을 선발하여 자급 조사료의 생산성을 높일 수 있는 재배 및 이용기술 보급이 시급하다 할 수 있다.

따라서 본 시험은 동계사료작물의 사초생산 성과 사료가치를 평가하여 제주지역에서 청보 리를 대체할 수 있는 사료작물을 탐색하고 제 주지역에 적합한 동계사료작물을 선발하는데 있다.

\section{․ 재료 및 방법}

본 시험은 제주에 있는 농촌진흥청 난지농업 연구소 시험포장에서 2007년 10월부터 2008년 6 월까지 수행되었다. 시험초종으로는 이탈리안 라이그라스 2품종 ('화산 101호' 및 'Florida-80'), 청보리 2품종(‘영양보리’ 및 ‘유연보리’), 귀리 2품종 (‘삼한’ 및 ‘Swan’), 밀 2품종(‘금강밀’ 및 ‘우리밀’), 트리티케일 (‘신영’)이다. 시험구는 초 종별로 난괴법 3반복으로 배치하였으며 시험구 당 면적은 $6 \mathrm{~m}^{2}$ 였다. 파종시기는 2007년 10월 12 일에 파종하였으며, ha 당 파종량은 이탈리 안 라이그라스가 $30 \mathrm{~kg}$, 청보리, 귀리, 밀, 트리 티케일이 각각 $180 \mathrm{~kg}$ 을 조파 하였다. 시험초종 의 시비량은 $150(\mathrm{~N})-120(\mathrm{P})-120(\mathrm{~K}) \mathrm{kg} / \mathrm{ha}$ 으로 하 였으며, 이탈리안 라이그라스는 질소를 기비로 $20 \%$, 이듬해 봄 추비로 $50 \%, 1$ 차 수확 후 $30 \%$ 를 시용하였으며 기타 사료작물은 기비로 $50 \%$, 봄 추비로 $50 \%$ 를 시용하였으며 $\mathrm{P}$ 와 $\mathrm{K}$ 는 기비 로 전량 시용하였다.

제주지역의 온도 및 강수량은 Table 1 에서 보는 바와 같다. 온도는 예년에 비하여 평균 $0.2^{\circ} \mathrm{C}$ 높았으며, 강수량은 예년보다 $130.2 \mathrm{~mm}$ 가 많았다.

이탈리안 라이그라스와 트리티케일은 출수기 에 수확하였으며 기타 동계사료작물은 가락이 노란색으로 변하는 호숙기에 수확하였다. 생초

Table 1. Mean temperature and precipitation at Jeju, 2007 to 2008

\begin{tabular}{|c|c|c|c|c|c|}
\hline \multirow{2}{*}{ Month } & \multicolumn{2}{|c|}{ Temperature $\left({ }^{\circ} \mathrm{C}\right)$} & & \multicolumn{2}{|c|}{ Precipitation $(\mathrm{mm})$} \\
\hline & $2007 \sim 2008$ & Normal & & $2007 \sim 2008$ & Normal \\
\hline October & 18.4 & 17.9 & & 41.8 & 7.8 \\
\hline November & 12.0 & 12.6 & & 1.2 & 7.1 \\
\hline December & 9.6 & 8.0 & & 14.1 & 4.4 \\
\hline January & 6.5 & 5.7 & & 24.3 & 6.1 \\
\hline February & 5.1 & 6.0 & & 7.9 & 7.2 \\
\hline March & 10.0 & 8.9 & & 17.4 & 8.1 \\
\hline Aril & 14.2 & 13.6 & & 20.8 & 9.3 \\
\hline May & 17.1 & 17.5 & & 41.9 & 8.7 \\
\hline Jun & 20.7 & 21.2 & & 38.5 & 19.0 \\
\hline Mean & 12.6 & 12.4 & Sum & 207.9 & 77.7 \\
\hline
\end{tabular}


수량은 전체구를 예취하여 ha 당 수량으로 환 산하였으며 건물수량은 각 처리구별로 약 300 $\sim 500 \mathrm{~g}$ 의 시료를 취하여 생초중량을 평량하고, $65^{\circ} \mathrm{C}$ 의 열풍순환 건조기에서 72 시간이상 건조 후 건물함량을 산출한 다음 ha당 수량으로 환 산하였다. 얻어진 건물시료는 20 mesh Mill로 분쇄한 후 이중마개가 있는 플라스틱 시료 통 에 보관하여 식물체분석에 이용하였다. 조단백 질 함량은 AOAC (1996)법에 의거하여 분석하 였고 $\mathrm{NDF}$ 및 $\mathrm{ADF}$ 함량은 Goering 및 Van soest (1970)법에서 사용되어지는 시약을 이용하 여 Ankom fiber analyzer (Ankom technology, 2005a, 2005b)로 분석하였다. TDN 함량은 $0.79 \times(88.9-\mathrm{ADF})$ 의 계산식에 의해서 산출하였 다. 통계처리는 SAS Enterprise Guide (Ver. $6.03,1988)$ 를 이용하였으며 분산분석을 실시하 였으며, 처리평균간 비교는 최소 유의차(LSD) 를 이용하였다.

\section{III. 결과 및 고찰}

\section{1. 생육특성}

제주지역에서 동계작물의 한해, 초장, 출수기 및 도복 등의 생육특성은 Table 2에서 보는 바 와 같다. 동계작물의 내한성은 모든 시험초종
에서 강하게 나타났으며, 특히 귀리의 경우 내 륙지방에서는 월동이 불량하거나 불가능하여 (Heo 등, 2003) 봄이나 가을에 단경기 작물로 만 이용되어지나 제주지역에서는 월동이 가능 하여 월동 동계작물로 이용 가능한 것으로 나 타났다. 고 등(2005)은 제주지역에 적합한 청예 용 및 곡실용 귀리 품종 선발시험에서 가을(11 월 14일)에 파종한 후 내한성을 조사한 결과 모두 월동이 가능한 것으로 보고하였다.

출수기는 품종과 숙기에 따라 다양하게 나타 났는데, 전체적으로 밀이 4월 5일로 가장 빨랐 으며 이탈리안 라이그라스 ‘화산 101호'가 5월 11 일로 가장 늦은 것으로 나타났다. 제주지역 에서 동계사료작물의 출수기는 내륙지방(수원) 과 비교하면 청보리는 14 일, 밀은 26일정도 빨 랐으며(서 등, 2004a) 이탈리안 라이그라스의 ‘화산 101호'는 9일, 'Florida-80'은 17일(농촌진 흥청, 2007) 정도 빠른 것으로 나타났다. 곡실 이 채워지고 가락과 곡실이 누렇게 변하는 호 숙기는 밀이 5월 9일에 도달하여 가장 빨랐고 귀리 ‘삼한' 품종이 5월 30일로 가장 늦은 것 으로 나타났다. 서 등(2007)은 영남지방에서 보 리, 밀과 호밀의 품종 선발시험에서 보리는 5 월 22일, 밀은 5월 26일, 호밀은 6월 3일로 제 주지역보다 호숙기에 도달하는 시기가 늦은 것 으로 나타났다.

Table 2. Agronomic characteristics of winter forage crops at Jeju

\begin{tabular}{llcccrc}
\hline \multicolumn{1}{c}{ Species } & \multicolumn{1}{c}{ Cultivar } & $\begin{array}{c}\text { Winter } \\
\text { hardiness } \\
(1 \sim 9)\end{array}$ & $\begin{array}{c}\text { Heading } \\
\text { stage } \\
\text { (date, month) }\end{array}$ & $\begin{array}{c}\text { Dough } \\
\text { stage } \\
\text { (date, month) }\end{array}$ & $\begin{array}{c}\text { Plant } \\
\text { height } \\
(\mathrm{cm})\end{array}$ & $\begin{array}{c}\text { Lodging } \\
\text { tolerance } \\
(1 \sim 9)\end{array}$ \\
\hline \hline Barley & Youngyang & 1 & 14 April & 15 May & 96 & 3 \\
& Yuyeon & 1 & 11 April & 12 May & 85 & 1 \\
\hline Oat & Samhan & 1 & 28 April & 30 May & 107 & 2 \\
& Swan & 1 & 16 April & 16 May & 126 & 1 \\
\hline Wheat & Kumkang & 1 & 5 April & 9 May & 82 & 1 \\
& Woori & 1 & 5 April & 9 May & 77 & 1 \\
\hline Triticale & Shinyoung & 1 & 18 April & - & 129 & 1 \\
\hline Italian ryegrass & Hwasan 101 & 1 & 11 May & - & 116 & 3 \\
& Florida-80 & 1 & 19 April & - & 107 & 2 \\
\hline
\end{tabular}

* Rating score : 1 = Excellent or strong, 9 = Worst or weak. 
초장은 트리티케일이 $129 \mathrm{~cm}$ 로 가장 컸으며 밀이 $77 \mathrm{~cm}$ 로 가장 작은 것으로 나타났으며 도 복은 밀과 트리티케일에서는 거의 나타나지 않 았으나 보리, 이탈리안 라이그라스와 귀리에서 발생하였다.

\section{2. 사초생산성}

제주지역에서 동계사료작물의 사초생산성은 Table 3에서 보는 바와 같다. 생초수량은 이탈 리안 라이그라스 (‘화산 101호' 및 'Florida 80') 가 128,667 과 $105,406 \mathrm{~kg} / \mathrm{ha}$ 로 가장 높게 나타 났으며 밀 (‘금강’ 및 ‘우리’)이 46,741과 45,333 $\mathrm{kg} / \mathrm{ha}$ 로 가장 낮은 것으로 조사되었다. 건물률 은 밀이 $32.7 \%$ 로 시험초종에서 가장 높게 나타 났으며 이탈리안 라이그라스가 20.2\%로 가장 낮게 나타났다. 이탈리안 라이그라스의 건물률 이 낮은 것은 출수기에 수확하였고 곡실을 이 용할 수 있는 다른 동계사료작물은 호숙기에 수확하여 상대적으로 건물률이 높은 것으로 생 각된다.

건물수량은 제주지역에서 2번 수확이 가능한 이탈리안 라이그라스가 가장 높게 나타났는데 만생종인 '화산 101 호'가 $25,951 \mathrm{~kg} / \mathrm{ha}$, 조생종
인 Florida 80 이 21,262 kg/ha로 만생종 수량이 더 높은 것으로 나타났다. 최 등 (2007)은 이탈 리안 라이그라스 신품종 선발 시험에서 제주지 역이 중부지역의 건물수량보다 대체로 높다고 보고하였다. 보리 (‘영양보리’ 및 ‘유연보리’)의 건물수량은 각각 15,543 과 $13,892 \mathrm{~kg} / \mathrm{ha}$ 로 나타 났는데 이는 김 등 (2006)이 보고한 수원지방의 올보리 품종의 $14,230 \mathrm{~kg} / \mathrm{ha}$ 와 비슷한 결과를 보였으나 호남지역의 총체보리 10 품종의 건물 수량보다는 높게 나타났다 (김 등, 2007).

제주지역에서 곡실을 이용할 수 있는 동계사 료작물 중 귀리의 건물수량은 국내 육성 품종 인 ‘삼한’ 귀리가 $22,556 \mathrm{~kg} / \mathrm{ha}$ 였으며 도입품종 인 Swan이 $21,152 \mathrm{~kg} / \mathrm{ha}$ 로 가장 높게 나타났다. Heo 등 (2003)은 삼한귀리 품종의 건물수량을 수원과 익산지역에서 평가한 결과 각각 8.1 과 $8.6 \mathrm{ton} / \mathrm{ha}$ 로 나타나 제주지역의 건물수량과 비 교하여 크게 낮은 것으로 나타났다. 또한 귀리 는 다른 동계사료작물에 비하여 곡실수량이 높 은 것으로 나타났는데, 고 등 (2005)은 제주지 역에서 귀리의 품종별 곡실수량을 평가한 결과 Swan 품종이 $8,300 \mathrm{~kg} / \mathrm{ha}$ 로 가장 높은 것으로 나타나 김 등 (2007)이 보고한 호남지역에서 재 배된 청보리의 곡실수량 $(4,875 \mathrm{~kg} / \mathrm{ha})$ 보다 높

Table 3. Forage yield of winter forage crops at Jeju

\begin{tabular}{|c|c|c|c|c|c|}
\hline \multirow{2}{*}{ Species } & \multirow{2}{*}{ Cultivar } & \multicolumn{3}{|c|}{ Yield (kg/ha) } & \multirow{2}{*}{$\begin{array}{l}\text { DM } \\
(\%)\end{array}$} \\
\hline & & Fresh & $\mathrm{DM}$ & TDN & \\
\hline \multirow[t]{2}{*}{ Barley } & Youngyang & 56,593 & 15,543 & 10,183 & 27.7 \\
\hline & Yuyeon & 45,926 & 13,892 & 9,544 & 30.4 \\
\hline \multirow[t]{2}{*}{ Oat } & Samhan & 77,778 & 22,556 & 14,730 & 28.9 \\
\hline & Swan & 78,704 & 21,152 & 13,536 & 26.8 \\
\hline \multirow[t]{2}{*}{ Wheat } & Kumkang & 46,741 & 15,201 & 10,509 & 32.7 \\
\hline & Woori & 45,333 & 14,815 & 10,188 & 32.7 \\
\hline Triticale & Shinyoung & 72,963 & 20,298 & 13,018 & 27.8 \\
\hline \multirow[t]{2}{*}{ Italian ryegrass* } & Hwasan 101 & 128,667 & 25,951 & 17,066 & 20.2 \\
\hline & Florida-80 & 105,406 & 21,262 & 13,929 & 20.2 \\
\hline Average & & 73,123 & 18,963 & 12,523 & 27.5 \\
\hline LSD(0.05) & & 9,583 & 3,236 & 2,211 & \\
\hline
\end{tabular}

* DM = dry matter, TDN = total digestibility nutrients.

* Italian ryegrass was harvested twice in the 2008 growing season. 
Table 4. Forage quality of winter forage crops at Jeju

\begin{tabular}{lcrcccc}
\hline \multirow{2}{*}{ Species } & \multirow{2}{*}{ Cultivar } & \multicolumn{4}{c}{ Forage quality(\%) } & \multirow{2}{*}{ RFV } \\
\cline { 3 - 5 } Barley & Youngyang & 9.9 & 55.4 & 29.6 & 65.5 & 110 \\
& Yuyeon & 10.4 & 46.7 & 25.6 & 68.7 & 137 \\
\hline \multirow{2}{*}{ Oat } & Samhan & 10.7 & 53.2 & 29.9 & 65.3 & 115 \\
& Swan & 9.8 & 56.5 & 31.5 & 64.0 & 106 \\
\hline Wheat & Kumkang & 10.8 & 46.4 & 25.0 & 69.1 & 139 \\
& Woori & 10.0 & 45.7 & 25.4 & 68.8 & 140 \\
\hline Triticale & Shinyoung & 9.9 & 53.3 & 31.3 & 64.1 & 113 \\
\hline Italian ryegrass & Hwasan 101 & 11.2 & 49.1 & 29.3 & 65.8 & 125 \\
& Florida-80 & 10.9 & 51.7 & 29.6 & 65.5 & 118 \\
\hline Average & & 10.4 & 50.9 & 28.6 & 66.3 & 123 \\
\hline LSD(0.05) & & 0.37 & 3.12 & 2.96 & 2.35 & \\
\hline
\end{tabular}

* $\mathrm{CP}=$ crude protein, $\mathrm{NDF}=$ neutral detergent fiber, $\mathrm{ADF}=$ acid detergent fiber.

$\mathrm{RFV}=$ relative feed value.

은 것으로 나타났다.

밀의 건물수량은 금강밀과 우리밀 (‘금강' 및 ‘우리’)이 각각 15,201 과 $14,815 \mathrm{~kg} / \mathrm{ha}$ 로 청보리 의 수량과 비슷한 것으로 나타났으나 청보리에 비해 성숙기가 빨라 (Table 2) 하계 사료작물의 파종시기를 앞당길 수 있을 것으로 생각된다. 동계사료작물의 $\mathrm{TDN}$ 수량은 건물수량과 비슷 한 경향을 보였다.

제주지역에서 동계사료작물의 사초생산성은 이탈리안 라이그라스가 가장 높은 것으로 나타 났으나 청보리와 같이 사료비 절감 차원에서 곡실효과를 고려한다면 귀리도 높은 생산성을 보여 제주지역에서는 청보리 대체 사료작물로 이용 가능할 것으로 판단된다.

\section{3.사료가치}

제주지역에서 동계사료작물의 사료가치는 Table 4에서 보는 바와 같다. 조단백질 함량은 이탈 리안 라이그라스 ('화산 101호' 및 'Florida 80') 가 11.2 와 $10.8 \%$ 로 가장 높게 나타났으며 밀 (‘금강' 및 ‘우리’)의 $\mathrm{NDF}$ 함량은 46.4와 45.7\%, $\mathrm{ADF}$ 함량은 25.0과 25.4\%로 가장 낮아 사료가 치가 가장 높은 것으로 나타났다. 서 등 (2007, 2004a, 2004b)은 권역별로 답리작 사료작물 최 대 생산을 위한 품종 선발 시험에서 밀이 다른 동계사료작물에 비해 사료가치가 높다고 하여 본 시험결과와 같은 결과를 보였다.

$\mathrm{TDN}$ 함량은 밀 (‘금강' 및 ‘우리’)이 69.1과 $68.8 \%$ 로 가장 높은 것으로 나타났으나 초종 간 차이가 $5 \%$ 내외로 큰 차이를 보이지 않았다. 호숙기에 수확한 청보리 ('영양' 및 ‘유연')의 $\mathrm{TDN}$ 함량은 65.5와 68.7\%로 내륙지방의 청보 리와 비슷한 경향을 보였으며 (김 등, 2007; 임 등, 2007), 귀리도 내륙지방과 비슷한 결과를 보였다(Heo 등, 2003). 제주지역 동계사료작물 의 사료가치는 초종 간에 유의성은 인정되나 $(\mathrm{p}<0.05)$ 변동 폭이 작아 제주지역에 적합한 동 계사료작물 선발시 사초생산성이 우수한 품종 선발에 중점을 두어야 할 것으로 생각된다.

\section{IV. 요 약}

본 시험은 제주지역에서 동계사료작물의 사 초생산성과 사료가치를 평가하여 청보리를 대 체할 수 있는 사료작물을 탐색하고 제주지역에 적합한 동계사료작물 선발을 목적으로 제주시 난지농업연구소 시험포장에서 2007년 10월부터 
2008년 6월까지 수행되었다. 제주지역에서 동 계사료작물의 내한성은 모두 우수하였다. 출수 기는 밀(‘금강’ 및 ‘우리’)이 4월 5일로 가장 빨 랐으며 ‘삼한' 귀리가 4월 28일로 가장 늦은 것으로 나타났다. 호숙기는 '금강'과 '우리' 밀 (5월 9일) > ‘유연' 보리(5월 12일) > 'Swan' 귀리(5월 16일) 순으로 나타났으며 초장은 '신 영, 트리티케일이 $129 \mathrm{~cm}$ 로 가장 크고 '금강' 밀이 $82 \mathrm{~cm}$ 로 가장 작은 것으로 나타났다. 사초 생산성은 이탈리안 라이그라스('화산 101호')의 생초수량이 $128,667 \mathrm{~kg} / \mathrm{ha}$, 건물수량이 25,951 $\mathrm{kg} / \mathrm{ha}$ 로 가장 생산성이 높았으며, 곡류 사료작 물 중 귀리(‘삼한’)의 건물수량이 $22,556 \mathrm{~kg} / \mathrm{ha}$ 로 가장 높았다. 사료가치에서 조단백질 함량 은 이탈리안 라이그라스(‘화산 101호’)가 $11.2 \%$ 로 높았고 밀이 $10.8 \%$ 로 곡류 사료작물 중 가 장 높았다. TDN 함량은 밀(‘금강’ 및 ‘우리’)이 69.1 과 $68.8 \%$ 로 가장 높은 것으로 나타났으나 초종 간 차이가 $5 \%$ 내외로 큰 차이를 보이지 않았다. 제주지역에서 동계사료작물은 수량적 인 측면에서는 이탈리안 라이그라스가 가장 우 수한 것으로 나타났으나 사료비 절감 등을 고 려하면 제주지역에서는 귀리나 밀도 곡실효과 를 얻을 수 있어 청보리 대체사료작물로 이용 가능할 것으로 생각된다.

\section{$\mathrm{V}$. 인 용 문 헌}

1. AOAC. 1996. Official Methods of Analysis. 16th ed. Assoc. Offic. Anal. Chem., Arlington, VA.

2. ANKOM Technology. 2005a. Method for Determining Neutral Detergent Fiber. ANKOM Technology, Fairport, NY. http://www.ankom.com/ 09_procedures/procedures2.shtml. Accessed May 8, 2005.

3. ANKOM Technology. 2005b. Method for Determining Acid Detergent Fiber. ANKOM Technology, Fairport, NY. http://www.ankom.com/09_procedures/ proceduresl.shtml. Accessed May 8, 2005.

4. Heo. H.Y., H.H. Park, M.J. Kim, S.W. Choi, K. G. Park, J.H. Nam, J.G. Kim, C.K. Lee and Y.
U. Kwon. 2003. A New Cold Tolerant, High Forage and Grain Yielding Winter Oat Cultivar “Samhan”. Korean J. Breed. 35(3):331-332.

5. Goering, H.K. and P.J. Van Soest. 1970. Forage fiber analysis. Agric. Handb. 379, U. S. Gov. Print. Office, Washington, DC.

6. SAS. 1988. SAS/STATR: User's Guide (Release 6.03), SAS Inst. Inc., Gary, NC.

7. 고서봉, 이희석, 나기준. 1976. 조사료 생산 작부 체계 확립시험. 제주농업시험장보고서. p. 59.

8. 고서봉, 황경준, 박형수, 고문석. 2005. 제주지역 에서 청예 및 곡실용 귀리 품종 선발. 한국초지 조사료학회. 제43회 학술발표회. pp. 168-169.

9. 김원호, 서 성, 신재순, 임영철, 김기용, 김찬호. 2006. 파종시기 및 파종량이 총체보리의 생육특 성 및 수량에 미치는 영향. 한국초지학회지 26(3):155-158.

10. 김원호, 서 성, 임영철, 신재순, 성병렬, 지희정, 이상진, 박태일. 2007. 호남지역 사료용 총체보리 우량품종 선발. 한국초지학회지 27(3):161-166.

11. 농촌진흥청. 2007. 2006년도 동계작물 신품종개 발공동연구 보고서. pp. 213.

12. 서 성, 김원호, 김종근, 최기준, 고종민, 임시규. 2007. 권역별 답리작 사료작물 최대 생산을 위한 적작목(품종) 선발. 3. 영남지방(밀양)을 중심으 로. 한국초지학회지 27(2):85-92.

13. 서 성, 김원호, 김종근, 최기준. 2004a. 권역별 답리작 사료작물 최대 생산을 위한 적작목(품종) 선발. 1. 중부지방(수원)을 중심으로. 한국초지학 회지 24(3):207-216.

14. 서 성, 김원호, 이준희, 박태일, 최기춘. 2004b. 답리작 사료작물 최대 생산을 위한 적작목(품종) 선발. 2. 호남지방(익산)을 중심으로. 한국초지학 회지 24(3):217-224.

15. 임영철, 윤세형, 김원호, 김종근, 최기준, 김맹중, 정민웅, 서성, 육완방. 2007. 중부지역 답리작에 서 동계 사료작물의 조기파종 효과. 한국초지학 회지. 27(3):183-188.

16. 최기준, 임영철, 성병렬, 김기용, 이종경, 임근발, 박형수, 서성, 지희정. 2007. 내한 조숙성 이탈리 안 라이그라스 신품종 '코스피드'. 한국초지학회 지. 27(3):145-150.

17. 최동윤, 조성백, 신재순, 이종언, 고서봉. 1993. 파종기별 청예용 귀리품종 선발. 제주농업시험장 보고서.

(접수일: 2008년 8월 7일, 수정일 1차: 2008년 8월 25일, 수정일 2차 9월 5일, 게재확정일: 2008년 9월 19일) 